\title{
Information Content Hypotesis Pada Saham Terindeks JII
}

\author{
Yayu Putri Senjani, Randi Irawan Wibantoro \\ UIN Sunan Kalijaga Yogyakarta \\ yayu.senjani@uin-suka.ac.id
}

\begin{abstract}
This research aims to test Information Content Hypothesis of Jakarta Islamic Index (JII) for stock prices. Two Independent Samples T-Test is used to test the difference of 195 stock prices in 39 companies entering and leaving the $5 \mathrm{JII}$ lists during 2015-2017. The result is that there are differences of stock prices when company is listed compared to the stock prices when the company is taken out in the JII list. The companies have higher stock prices when it entered than when it is excluded in JII.

Keyword: Information Content Hypothesis, Stock Price, Jakarta Islamic Index, Sharia Stock Index

Abstrak

Penelitian ini bertujuan untuk menguji Information Content Hypothesis Jakarta Islamic Index (JII) terhadap harga saham. Two Independent Samples T-Test digunakan untuk menguji perbedaan 195 harga saham pada 39 perusahaan ketika masuk dan keluar dalam 5 daftar JII selama tahun 2015-2017. Hasil analisis menunjukkan bahwa terdapat perbedaan harga saham ketika perusahaan dinyatakan terdaftar dalam indeks JII dibandingkan harga saham ketika perusahaan tersebut dikeluarkan dari daftar JII. Perusahaan memiliki harga saham lebih tinggi ketika terdaftar dibandingkan ketika keluar dari daftar JII.
\end{abstract}

Kata Kunci: Information Content Hypothesis, Harga Saham, JII, Indeks Saham Syariah

Diterima: 7 Agustus 2108; Revisi: 2018; Disetujui: 2018 


\section{PENDAHULUAN}

Di tengah perkembangan ekonomi Syariah, terdapat dampak bagi dunia pasar modal Syariah. Salah satu hal yang menunjukan perkembangan pasar modal Syariah adalah respon dari Bursa Efek Indonesia (BEI) terhadap keberadaan saham Syariah. Berdasarkan informasi yang diperoleh dari website BEI, (www.idx.co.id), sejak November 2007, OJK telah mengeluarkan Daftar Efek Syariah (DES) yang berisi daftar Saham Syariah yang ada di Indonesia. Keberadaan DES tersebut kemudian ditindaklanjuti oleh BEI dengan meluncurkan Indeks Saham Syariah Indonesia (ISSI) pada tanggal 12 Mei 2011. Selama ini, investasi Syariah di pasar modal Indonesia identik dengan Jakarta Islamic Index (JII) yang hanya terdiri dari 30 saham Syariah yang tercatat di Bursa Efek Indonesia (BEI).

JII merupakan yang salah satu indeks saham yang ada di Indonesia yang menghitung indeks harga rata-rata saham untuk jenis saham-saham yang memenuhi kriteria atau prinsip syariah Islam. JII didirikan untuk merespon kebutuhan masyarakat terhadap instrumen syariah yang semakin berkembang. Tujuan pembentukan JII adalah untuk meningkatkan kepercayaan investor dan memberikan manfaat bagi pemodal dalam menjalankan syariah Islam untuk melakukan investasi di bursa efek. JII juga diharapkan dapat mendukung proses transparansi dan akuntabilitas saham berbasis syariah di Indonesia. Dengan kata lain, JII menjadi pemandu bagi investor yang ingin menanamkan dananya secara syariah tanpa takut tercampur dengan cara dana ribawi. Selain itu, JII menjadi tolak ukur kinerja dalam memilih portofolio saham yang halal, karena sesuai dengan prinsip syariah dalam islam (Kurniawan \& Asandimitra, 2014: 1356).

Pergerakan harga saham Syariah sama dengan saham pada umumnya. Perubahan harga dipengaruhi oleh kondisi pasar modal. Sartono dalam Sasanti (2005) mengemukakan bahwa harga pasar saham terbentuk melalui mekanisme permintaan dan penawaran di pasar modal. Salah satu ciri pasar modal yang efisien adalah ketersediaan informasi yang cukup untuk semua pelaku pasar modal.

BEI selalu mempublikasikan daftar saham yang masuk ke dalam beberapa indeks terutama JII. Dengan kriteria tertentu, JII menjadi tolak ukur kinerja 
perusahaan yang professional dan menjalankan bisnis yang sesuai dengan Syariah Islam. Perusahaan yang masuk dalam indeks harga saham bereputasi tentu diharapkan menggambarkan kondisi real manajemen perusahaan. Ketika perusahaan diumumkan masuk dalam daftar indeks saham yang likuid maka diduga dapat mempengaruhi harga pasar saham tersebut. Teori yang terkait dengan hal tersebut dikenal dengan Information Content Hypothesis.

Teori Information Content Hypothesis muncul dari penelitian-penelitian tentang pengaruh konten informasi dalam pengumuman deviden. Information Content Hypothesis menunjukkan masuk dan keluarnya suatu saham dari sebuah indeks merupakan informasi baru yang mengindikasikan prospek masa depan dari saham tersebut (Duque dan Madeira; 2005). Dividen menyampaikan informasi tentang laba di masa mendatang. Informasi tersebut memungkinkan partisipan pasar untuk memprediksi laba mendatang dengan lebih akurat. (Watts, 1973). Hubungan konten informasi dividen dengan harga saham sering diteliti di bidang penelitian keuangan. Sebagai contoh hasil temuan pada penelitian yang dilakukan oleh Golda (2005). Information Content terbukti pada pengumuman dividen tunai naik dan dividen tunai tetap. Hal ini karena harga pasar bereaksi pada saat dua kondisi tersebut. Temuan yang sama oleh Siaputra dan Atmadja (2006) yang menyatakan bahwa terdapat pergerakan saham yang signifikan sejak 15 hari sebelum dan 15 hari setelah pengumuman dividen.

Sementara itu, hipotesis ini mulai dilakukan untuk jenis konten informasi selain dividen. Definisi lain tentang Information Content Hypothesis menyatakan bahwa pergerakan harga saham pada perusahaan yang masuk indeks maupun keluar disebabkan adanya kandungan informasi dari perubahan komposisi indeks. Rahman (2007) dalam Wibantoro (2018) menyatakan bahwa kandungan informasi yang dimaksud dalam hipotesis ini adalah informasi nonpublik yang dimiliki oleh pihak yang menentukan komposisi indeks. Sementara Duque dan Madeira (2005) mendefinisikan Information Content Hypothesis dari perspektif yang berbeda. Masuk atau keluarnya suatu saham dari sebuah indeks adalah informasi baru yang mengindikasikan prospek masa depan dari saham tersebut. 
Jika saham suatu perusahaan masuk dalam sebuah indeks, perusahaan tersebut akan mendapat perhatian yang lebih besar dari pelaku pasar sehingga keterbukaan dan ketersediaan informasi mengenai perusahaan tersebut meningkat. Pada akhirnya, hal ini akan membuat harga saham perusahaan tersebut juga meningkat dan akan mengurangi risiko investasi akibat kurangnya informasi yang relevan.

Masyarakat di Indonesia memiliki minat yang cukup besar terhadap investasi berbasis syariah dikarenakan instrumen berbasis syariah merupakan alternatif lain bagi masyarakat muslim. Tidak semua lahan investasi yang dikenal oleh masyarakat di Indonesia sesuai dengan asas Islam, tetapi investasi berbasis syariah ini juga bisa digunakan untuk masyarakat umum.

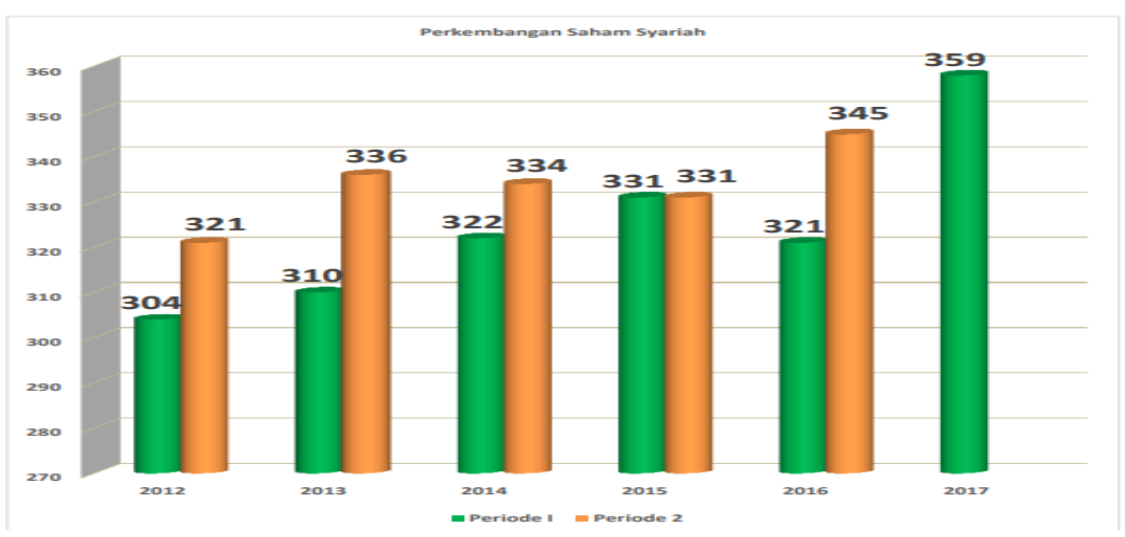

Gambar 1 Jumlah Saham Syariah dalam Daftar Efek Syariah (DES)

Sumber: www.ojk.go.id

Grafik batang di atas menggambarkan pertumbuhan saham syariah di Indonesia yang ditetapkan oleh Dewan Efek Syariah (DES) mulai tahun 2012 sampai 2017 per semester. Pada semester pertama terlihat di tahun 2012 sampai tahun 2015, pertumbuhan saham syariah meningkat, sebelum kemudian di tahun 2016 sempat menurun, tetapi di tahun selanjutnya 2017 saham syariah kembali meningkat drastis. Sedangkan pada semester kedua, terlihat bahwa di tahun 2012 sampai 2013 saham syariah meningkat, akan tapi di tahun 2014 sampai 2015 saham syariah sempat menurun, sebelum kemudian di tahun 2016 saham syariah meningkat kembali. (Wibantoro, 2018). 
Saham syariah merupakan salah satu bentuk dari saham biasa yang memiliki karakteristik khusus yang berupa kontrol ketat dalam hal kehalalan ruang lingkup kegiatan usaha. Saham syariah dimasukkan dalam perhitungan Jakarta Islamic Index merupakan indeks yang dikeluarkan oleh PT. Bursa Efek Indonesia yang merupakan subjek dari Indeks Harga Saham Gabungan (Yuliana, 2010). Saham Syariah adalah saham perusahaan yang sesuai dengan prinsip syariah. Daftar saham syariah secara keseluruhan terdapat dalam DES (Daftar Efek Syariah). Saham-saham yang masuk dalam indeks syariah adalah emiten yang kegiatan usahanya tidak bertentangan dengan syariah Islam. dan memenuhi syarat yang disebutkan dalam Fatwa Dewan Syariah Nasional Majelis Ulama Indonesia No: 20/DSN-MUI/IX/2000 tentang Pedoman Pelaksanaan Investasi untuk Reksadana Syariah.

Menurut fatwa DSN MUI nomor 40/DSN-MUI/X/2003, definisi efek Syariah adalah efek sebagaimana dimaksud dalam peraturan perundang-undangan di bidang pasar modal yang akad, pengelolaan perusahaan, maupun cara penerbitannya memenuhi prinsip syari'ah. Prinsip dasar saham Syariah dalam pengelolaan perusahaan yaitu perusahaan penerbit saham tidak boleh menjalankan usaha yang mengandung perjudian, riba dan memproduksi barang yang diharamkan (Sunariyah, 2003). Dalam teori ekonomi Islam, menjelaskan prinsip dasar dalam transaksi yang dilarang dalam Islam termasuk dalam pasar modal Syariah adalah transaksi yang mengandung unsur riba, gharar (ketidakpastian), maysir (judi) dan manipulasi.

Saham biasa maupun saham Syariah sama-sama memiliki harga untuk menggambarkan nilainya. Harga saham diartikan sebagai harga pasar (market value) yaitu harga saham yang ditemukan dan dibentuk oleh mekanisme pasar modal. Harga saham pada hakikatnya merupakan penerimaan besarnya pengorbanan yang harus dilakukan oleh setiap investor untuk penyertaan dalam perusahaan (Tumandung, 2017). Menurut Darmadji dan Fakhruddin (2001) harga saham dibentuk karena adanya pemintaan dan penawaran atas saham. Permintaan dan penawaran tersebut terjadi karena adanya banyak faktor, baik yang sifatnya 
spesifik atas saham tersebut (kinerja perusahaan dan industri dimana perusahaan tersebut bergerak) maupun faktor yang sifatnya makro seperti kondisi ekonomi negara, kondisi sosial dan politik, maupun informasi-informasi yang berkembang.

Investasi syariah yang banyak diminati masyarakat Indonesia yaitu pada indeks harga saham yang merupakan kumpulan dari beberapa saham yang terkelompok berdasarkan kategori-kategori tertentu. Sampai tahun 2018, BEI mempunyai beberapa macam indeks harga saham yaitu, Indeks Harga Saham Gabungan (IHSG), Indeks Sektoral, Indeks Kompas 100, Indeks Bisnis, Indeks LQ45, Indeks Saham Syariah Indonesia (ISSI), Jakarta Islamic Index (JII), dan JII 70.

Indonesia memiliki 3 Indeks yang mencantumkan DES yaitu Indeks Saham Syariah Indonesia (ISSI), Jakarta Islamic Index (JII) dan JII 70. ISSI adalah indikator kinerja seluruh saham Syariah yang tercatat di BEI dan masuk dalam DES yang diterbitkan oleh OJK. JII hanya mencantumkan 30 saham Syariah yang paling likuid yang tercatat di BEI. Sedangkan JII 70 sama seperti JII namun jumlah saham sebanyak 70 dan mulai diluncurkan pada bulan Mei 2018. Reviu saham Syariah yang masuk dalam daftar indeks masing-masing di atas dilakukan dua kali dalam setahun dan diumumkan pada bulan Mei dan November.

Menurut DSN-MUI, jenis kegiatan utama perusahaan yang tidak akan tergolong dalam DES adalah:

a. Usaha perjudian dan yang tergolong judi atau perdagangan yang dilarang.

b. Usaha lembaga keuangan konvensional (ribawi) termasuk perbankan dan asuransi konvensional.

c. Usaha yang memproduksi, mendistribusi serta memperdagangkan makanan dan minuman yang tergolong haram.

d. Usaha yang memproduksi, mendistribusi dan menyediakan barang-barang ataupun jasa yang merusak moral dan bersifat mudarat.

BEI menetapkan kriteria pemilihan saham Syariah yang akan masuk dalam daftar JII adalah sebagai berikut:

a. Kumpulan saham dengan jenis usaha utama yang tidak bertentangan dengan prinsip syariah dan sudah tercatat lebih dari tiga bulan (kecuali termasuk dalam 10 kapitalisasi besar). 
b. Saham yang berdasarkan laporan keuangan tahunan atau tengah tahun memiliki rasio kewajiban terhadap aktiva maksimal sebesar 90\%.

c. 60 saham dari susunan saham berdasarkan urutan rata-rata kapitalisasi market tahun terakhir.

d. 30 saham dengan urutan berdasarkan tingkat likuiditas rata-rata nilai perdagangan regular selama satu tahun terakhir.

Saham-saham yang masuk dalam perhitungan JII selalu dievaluasi ketaatannya terhadap prinsip-prinsip syariah sebagaimana tertuang dalam fatwa DSN. Apabila saham-saham tersebut tidak lagi memenuhi prinsip-prinsip syariah dan kriteria yang ditentukan, BEI akan mengeluarkannya dari JII dan kedudukannya digantikan oleh saham lain yang memenuhi prinsip-prinsip syariah dengan jumlah yang sama setiap periodenya yaitu 30 saham (Nafik, 2009).

Evaluasi yang dilakukan adalah tiap 6 bulan sekali dengan penentuan komponen indeks awal bulan Januari dan Juli setiap tahunnya. Sedangkan perubahan pada jenis usaha emiten akan dimonitori secara terus menerus berdasarkan data publik dan media. Indeks harga sahan setiap hari dihitung menggunakan harga saham terakhir yang terjadi di bursa (Qoyum, 2017).

Wibantoro (2018) menemukan bahwa terdapat pengaruh indeks saham Syariah terhadap harga saham. Dengan menggunakan teori Information Content pengumuman Indeks Saham Syariah dalam JII terhadap harga saham, maka hipotesis pada penelitian ini adalah:

H1: Terdapat perbedaan antara harga saham saat berada dalam daftar JII dibandingkan ketika dikeluarkan dari daftar.

H2 : Harga Saham bernilai lebih tinggi ketika perusahaan berada dalam daftar JII dibandingkan dengan ketika dikeluarkan dari daftar.

\section{METODE}

Populasi dalam penelitian ini adalah perusahaan go public yang terdaftar di BEI. Untuk memastikan bahwa hipotesis konten informasi berfungsi dalam analisis ini, maka pemlilihan sampel dilakukan dengan metode pengambilan sampel 
nonprobabilitas yang memenuhi kriteria tertentu, teknik ini disebut juga purposive sampling (Cooper dan Schindeler, 2012). Kriteria perusahaan yang menjadi sampel adalah pernah masuk dalam 5 (lima) daftar JII selama periode penelitian (20152017).

Jenis data yang digunakan adalah data sekunder berupa harga saham dan daftar perusahaan terdaftar dalam JII yang dipublikasikan oleh OJK setiap dua kali dalam setahun. Harga saham yang digunakan adalah harga saham penutupan 1 hari setelah tanggal pengumuman indeks. Status masuk dan keluarnya dalam indeks JII ditentukan berdasarkan Pengumuman BEI pada bulan Mei dan November setiap tahun pengamatan. Berdasarkan kriteria tersebut diperoleh 39 perusahaan yang pernah masuk dalam daftar JII selama tahun 2015-2017.

Untuk menguji hipotesis, penelitian ini menggunakan alat analisis statistik two independent samples test pada software SPSS. Two independent sample test digunakan untuk menguji signifikansi beda rata-rata dua kelompok untuk data berjumlah kurang dari 200 dan tidak berdistribusi normal (Trihendradi, 2012). Untuk mengetahui arah perubahan yang terjadi, maka dilakukan analisis deskritptif statistik dari data harga saham ketika berada di luar maupun dalam daftar JII.

\section{HASIL DAN PEMBAHASAN}

Objek penelitian ini adalah perusahaan go public yang pernah terdaftar dalam JII pada tahun 2015-2017 selama 5 periode pengumuman. Selama 3 tahun tersebut BEI rutin menerbitkan DES yang memenuhi kriteria untuk diakui sebagai saham Syariah yang likuid. Setiap tahun terdapat dua kali pengumuman yaitu pada bulan Mei dan November. Hanya 30 perusahaan yang masuk di setiap pengumuman DES JII. Namun untuk periode 2015-2017 terdapat 39 perusahaan yang pernah terdaftar dalam JII sekaligus menjadi sampel dalam penelitian ini.

Berdasarkan analisis deskriptif, berikut adalah informasi yang terkait dengan kedua variabel yang diuji yaitu status indeks JII dan harga saham:

Tabel 2 Deskripsi Harga Saham untuk Setiap Status dalam Indeks JII 


\begin{tabular}{llcc}
\hline \multicolumn{1}{c}{ Status Indeks } & Mean & Min & Max \\
\hline Dimasukan ke daftar JII & $3.894,22$ & 188 & 19.975 \\
Dikeluarkan dari daftar JII & $7.147,81$ & 123 & 46.175
\end{tabular}

Sumber: Data diolah

Dengan memperhatikan tabel 2, ditunjukkan bahwa rata-rata harga saham ketika perusahaan masuk dalam daftar JII lebih tinggi dibandingkan ketika perusahaan dinyatakan keluar dari daftar JII. Selain melakukan analisis deskriptif terhadap variabel dan sebelum dilakukan uji beda, maka dilakukan uji normalitas data terlebih dahulu. Dengan menggunakan alat analisis Shapiro Wilk, ditemukan bahwa data tidak berdistribusi normal.

Dalam melakukan uji beda antara harga saham ketika berada di dalam dan di luar daftar JII harus menggunakan statistik non-paramaterik. Statistik nonparametrik disebut juga statistik bebas distribusi karena tidak diharuskan data yang akan dianalisis berdistribusi normal. Uji beda dua variabel independen dalam statistik non-parametrik adalah two independent samples test. Berdasarkan jumlah data yang kurang dari 200, maka uji yang dipilih adalah uji Mann-Whitney. (Trihendradi, 2012).

Tabel 3 Hasil Uji Mann-Whitney

\begin{tabular}{lr}
\hline & \multicolumn{1}{c}{ Stock Price } \\
\hline Mann-Whitney U & 2511.500 \\
Wilcoxon W & 3546.500 \\
Z & -2.601 \\
Asymp. Sig. (2-tailed) & .009 \\
\hline Sumber: Data diolah &
\end{tabular}

Table 3 menunjukkan hasil untuk uji hipotesis penelitian dengan menggunakan two independent samples test Mann-Whitney. Nilai signifikansi yang menunjukkan angka 0,009 $(<0,050)$ berarti menolak hipotesis nol atau menerima 
hipotesis alternatif. Dengan demikian, hipotesis pertama pada penelitian ini yang menyatakan bahwa terdapat perbedaan antara harga saham saat berada dalam daftar JII dibandingkan ketika dikeluarkan dari daftar, dinyatakan diterima.

Untuk menjawab hipotesis dua, kita dapat mengacu pada nilai mean (ratarata) harga saham ketika berada di dalam dan di luar daftar JII. Pada tabel 1 tentang statistik deskriptif data penelitian menunjukkan rata-rata harga saham ketika dimasukkan ke daftar JII lebih tinggi dibandingkan ketika harga saham perusahaan tersebut dikeluarkan dari daftar JII. Hal tersebut berarti bahwa hipotesis kedua juga diterima.

\section{SIMPULAN}

Berdasarkan hasil analisis, penelitian ini menunjukkan bahwa informasi sangat penting untuk pengambilan keputusan. Informasi bahwa perusahaan dianggap berkinerja baik karena berhasil masuk dalam indeks saham yang bagus, maka investor akan meresponnya sehingga berpengaruh terhadap harga saham. Apalagi JII yang merupakan kombinasi antara kriteria kinerja keuangan dan kriteria yang berkaitan tentang prinsip Syariah.

Penelitian ini berbeda dengan penelitian-penelitian sebelumnya yang membandingkan antara perusahaan yang terdaftar dengan yang tidak terdaftar pada JII. Untuk membuktikan Information Content Hypothesis, maka yang dibandingkan adalah data ketika perusahaan tersebut masuk dan keluar dalam daftar saham Syariah di JII. Harga saham ketika perusahaan termasuk dalam JII berbeda signifikan dengan ketika perusahaan dikeluarkan dari daftar oleh BEI. Rata-rata harga saham pun menunjukkan angka yang lebih tinggi ketika saham perusahaan masuk menjadi anggota DES JII. Hal ini menunjukkan informasi masuk dan tidaknya saham pada indeks tertentu mempengaruhi keputusan investor yang berdampak pada perubahan harga saham.

Meskipun telah membuktikan ketepatan Information Content Hypothesis, penelitian ini memiliki keterbatasan. Data yang dianalisis hanya harga saham yang hubungannya melekat pada indeks. Studi berikutnya dapat menambahkan jenis data dan informasi lain yang lebih luas dan representatif lagi. 


\section{PUSTAKA ACUAN}

Cooper, Donald R. dan Pamela S. Schinder. 2012. Business Research Methods, 12th Edition. New York: McGraw Hill.

Darmadji, Tjiptono dan Fakhruddin, Hendy M. 2011. Pasar Modal di Indonesia. Pendekatan Tanya Jawab. Edisi ketiga. Jakarta: Salemba Empat.

Duque, João dan Madeira, Gustavo. 2005. Effects Associated with Index Composition Changes: Evidence from Euronext Lisbon Stock Exchange. Journal of Business.

Fatwa Dewan Syariah Nasional Majelis Ulama Indonesia No: 20/DSN-MUI/IX/2000 tentang Pedoman Pelaksanaan Investasi untuk Reksadana Syariah

Fatwa Dewan Syariah Nasional Majelis Ulama Indonesia No: 40/DSN-MUI/IX/2003 tentang Pasar Modal dan Pedoman Umum Penerapan Syariah di Bidang Pasar Modal.

Golda, Zainafree. 2005. Reaksi Harga Saham Terhadap Pengumuman Pembayaran Dividen Tunai di Bursa Efek Jakarta. Master Thesis. Universitas Diponegoro.

HR, Muhamad Nafik. 2009. Bursa Efek \& Investasi Syariah. Jakarta: PT Serambi Ilmu Semesta

Kurniawan, Rizki Dwi dan Asandimitra, Nadia. Oktober 2014. Analisis Perbandingan Kinerja Indeks Saham Syariah Dan Kinerja Indeks Saham Konvensional. Jurnal Ilmu Manajemen. Vol. 2, No. 4.

Putri, Sherly Arnandia. 2017. Pengaruh Kinerja Keuangan Terhadap Harga Saham Studi Pada Perusahaan Jakarta Islamic Index. Jurnal Ilmu dan Riset Akuntansi. Vol. 6, No. 7, ISSN: 2460-0585.

Qoyum, Abdul. 2017. Lembaga Keuangan Islam di Indonesia. Yogyakarta: Elmater Publishing.

Sasanti, Retno. Widya dan Nurfauziah. 2005. Analisis Faktor-Faktor yang Berimplikasi terhadap Fluktuasi Harga Saham di Bursa Efek Jakarta. Jurnal Sinergi:Kajian Bisnis dan Manajemen. Edisi khusus on Finance. Hal. 53-66. 
Siaputra, Lani dan Adwin Surja Atmadja. 2006. Pengaruh Pengumuman Dividen Terhadap Perubahan Harga Saham Sebelum dan Setelah Ex-Dividend Date di Bursa Efek Jakarta (BEJ). Jurnal Akuntansi dan Keuangan. Vol. 8, No. 2.

Sunariyah. 2006. Pengantar Pengetahuan Pasar Modal. Yogyakarta: UPP STIM YKPN.

Tumandung, Cristin Oktavia. 2017. Analisis Pengaruh Kinerja Keuangan Terhadap Harga Saham Pada Perusahaan Makanan dan Minuman Yang Terdaftar di BEI Periode 2011-2015. Jurnal EMBA. Vol. 5, No. 2, ISSN: 2303-1174.

Trihendradi, C. 2012. Step by Step SPSS 20 Analisis Data Statistik. Yogyakarta: Andi Offset.

Watts, Ross. 1973. The Information Content of Dividends. The Jorunal of Business. Vol. 46, No. 2. Hal: 191-211.

Wibantoro, Randi Irawan. 2018. Pengaruh Analisis Fundamental Terhadap Harga Saham Ditinjau Berdasarkan Perspektif Internal dan Eksternal Perusahaan (Studi Kasus Pada Jakarta Islamic Index Periode 2012-2016). Skripsi. UIN Sunan Kalijaga Yogyakarta

Bursa Efek Indonesia. 2015. Pengumuman Perubahan Komposisi Saham dalam Penghitungan Jakarta Islamic Index. Nomor 343.

Bursa Efek Indonesia. 2015. Pengumuman Perubahan Komposisi Saham dalam Penghitungan Jakarta Islamic Index. Nomor 955

Bursa Efek Indonesia. 2016. Pengumuman Perubahan Komposisi Saham dalam Penghitungan Jakarta Islamic Index. Nomor 301.

Bursa Efek Indonesia. 2016. Pengumuman Perubahan Komposisi Saham dalam Penghitungan Jakarta Islamic Index. Nomor 917.

Bursa Efek Indonesia. 2017. Pengumuman Perubahan Komposisi Saham dalam Penghitungan Jakarta Islamic Index. Nomor 371.

www.dsnmui.or.id. Fatwa

www.duniainvestasi.com Data Harga Saham

www.idx.co.id. Saham dan Saham Syariah

www.ojk.go.id. Pasar Modal Syariah

www.sahamok.co.id. Jakarta Islamic Index (III) 